\title{
Financial Management Practical Teaching Content System Construction Based on Cultivating Value Creation Ability
}

\author{
Hui-ling Cheng ${ }^{1,}$, and Ying Jiang ${ }^{2, b}$ \\ ${ }^{1,2}$ School of management, Beijing Normal University Zhuhai Campus, Zhuhai 519087, China \\ a chenghl@bnuz.edu.cn, ${ }^{\mathrm{b}}$.jpz6311whu@bnuz.edu.cn.
}

Keywords: Financial management; practical teaching; value creation ability.

\begin{abstract}
At first, this paper points out that cultivating the financial management talents with value creation ability are an urgent need for our country's economic transition at first. Then, taking Financial Management of Beijing Normal University Zhuhai Campus as an example, it analyzes the current situation of financial management practical teaching, and puts forward the original ideas of constructing financial management practical teaching content system, which aims at cultivating the students' value creation ability.
\end{abstract}

\section{An Urgent Need to Cultivate the Financial Management Talents with Value Creation Ability for Our Country's Economic Transition}

On October 27, 2014, according to Twelfth five-year plan for accounting reform and development, Ministry of Finance published the Guidance with respect to comprehensively promoting management accounting system construction (hereinafter referred to as the Guidance). At present, there are 16.6 million accountants in our country. However, a particular lack of top financial management talents who can provide useful decision-making information for their senior managers has become a serious bottleneck hindering enterprises' development. The Guidance points out that promoting management accounting system construction is an urgent need for our country to promote economic transition, a system arrangement for enterprise to establish modern enterprise system and increase value creation ability as well as a vital orientation for accounting reform and development. ${ }^{[1]}$

\section{The Current Situation of Financial Management Practical Teaching}

Since the financial management major was set up in 2011, it has been always taking the cultivation of applied, export-oriented and versatile financial management talents as a goal. Four educational innovation principles, namely, internationalization, applicability, regionalization and individuation, have been insisted in the process of cultivating talents. School leaders at all levels have paid high attention to practical teaching all the time. In terms of financial management practical teaching curriculum, some popular professional practice courses such as Accounting Simulation Practice By Hand, Accounting Information System, and Financial Management Decision-making Training are opened in our major. Additionally, individual professional practice courses are also offered in our major. For example, Tutor Workshop, Professional Quality Forming and so on, it should be mentioned that these courses offered have made a great contribution to cultivating applied talents. However, financial management practical teaching system has not yet been established. The most serious problems are shown as follows: practical teaching target orientation is not clear, profession feature of practical teaching content is not prominent, which mainly presented as follows: part of campus practical teaching content is the same as that of accounting profession, and professional practice outside school stays within the primary level. It is difficult for most students in professional practice to actually go deep into financial management activities of enterprises. At most, they can assist others in preparing vouchers or running up an account. For these reasons, the employment competence of financial management students has been seriously weakened to some extent. Financial management is an independent and applied subject that mixes the knowledge of accounting, management and finance together. It is mainly reflected in a series of activities that conduct value 
management for financial behaviors such as financing, investment, day-to-day fund operations, profit distribution and so on. Its ultimate goal is enterprise value maximization. It should be distinguished from accounting that performs information management for economic activities given priority to capital movement. So, how to build a financial management practical teaching system aims to strengthen profession features based on cultivating students' value creation ability is an urgent need for profession construction reform.

\section{Financial Management Practical Teaching Content System Construction Based on Cultivating Value Creation Ability}

\subsection{Cultivating Students' Value Creation Ability is taken as a Goal of Practical Teaching System.}

As the soul of the practice teaching system, goal system decides the content construction of practical teaching and is the key factor affecting practical teaching effects. Hence, we should take cultivating students' value creation ability as goal orientation, renew the idea of practical teaching, increase investment in the practical teaching time, improve the practical teaching links and establish financial management practical teaching system of distinct hierarchy, clear logic and professional features. Taking zhujianhua's relevant research achievements as reference, according to his doctoral dissertation "Research on Enterprises' Financial Management Capability System Establishment and Certification in China” in 2013, the necessary financial management capacity for enterprise value creation can be classified into three broad categories: internal resources management ability, external resources integration and coordination ability and risk management ability.

\subsection{Hierarchically Construct Practical Teaching Content System.}

Practical teaching content system is the core part of the whole practical teaching system and the specific embodiment of practical teaching goal. Practical teaching contents can be divided into three levels: basic practice, professional practice and comprehensive practice. In order to keep pace with times, it should stand on the point of the forefront of profession, keeping stable in short period while updating dynamically in long period (within a talent training cycle).

\subsubsection{Basic Practice.}

Basic practice contents include all kinds of courses such as in-class basic experiments, computer operating, training, cognition practice, public welfare activities, social survey and extra-curricular activities in science and technology. Great oaks from little acorns grow. In the first of school year, through Introduction to Financial Management, the freshmen should fully understand that the goal for our major is cultivating senior financial management talents who can create value for enterprises in the first school year. Then, by Tutor Workshop, they should make a plan for their study in the coming four years. Next, they can learn professional basic practice work by financial management cognition practice, which lays a foundation for later study. Meanwhile, theory and practice in the basic practice courses should be integrated and not be separated artificially. For example, after Basic Accounting has been opened, then 8-credit-hour Basic Accounting Training should been offered directly in order to consolidate the students' professional foundation, as an old saying goes, strike while the iron is hot.

\subsubsection{Professional Practice.}

Professional practice contents include comprehensive, designing experiments, course design, course paper, professional practice and so on. To realize the goal of cultivating students' enterprise value creation ability, we must innovate professional core practical courses as shown table 1 .

The professional core practice courses above-mentioned should be set up closely around cultivating the three broad capacities. Taking Financial Management Decision-making Training as an example, giving the related contents of a case company such as financial goal, product brief introduction, capacity, market conditions, corporate governance structure, business risk factors and solutions, as well as financial statements, the teacher should guide students to discuss and analyze independently how to make rational decisions on all kinds of financial management activities to maximize enterprise value, including business day-to-day operation, investment and financing, and 
allocation of profits. In the training course of The Application of Management Accounting Tools, students can use management accounting tools to make an effective planning, control and decision-making for case company's value management activities. From the point view of not violating the law, Tax Planning Case Analysis explores how to reduce the corporate tax burden level to further realize enterprise value maximization. From the perspective of informatization, Comprehensive Training in ERP mainly implements enterprise resources management timely. These practical courses above-mentioned are set up tightly around cultivating students' internal resources management ability. Combined with case company, Capital Operation Case Analysis analyzes how to integrate corporate strategic resources by different ways such as merger, purchase, combination and separation to further realize enterprise strategic goals. In this process, the benefits of different stakeholders need to be harmonized. So, Stakeholder Management Case Analysis aims to cultivate students' ability of coordinating the external financial relationship. The two courses are set up tightly around cultivating students' external resources integration and coordination ability. At last, Internal Audit Case Analysis, Internal Control System Design and Risk Management and Control Case Analysis mainly cultivate students' internal control and risk management ability, which holds up an umbrella for enterprises’ value management activities.

Table 1. Financial Management Core Practical Teaching Innovative Courses

\begin{tabular}{c|c}
\hline $\begin{array}{c}\text { The necessary financial management capacity for } \\
\text { enterprise value creation }\end{array}$ & The corresponding courses \\
\hline \multirow{2}{*}{\begin{tabular}{c} 
Internal resources management ability \\
\cline { 2 - 2 } External resources integration\&coordination ability
\end{tabular}} & $\begin{array}{c}\text { Financial Management Decision-making } \\
\text { Training }\end{array}$ \\
\cline { 2 - 2 } & $\begin{array}{c}\text { The Application of Management Accounting } \\
\text { Tools }\end{array}$ \\
\cline { 2 - 2 } & Comprehensive Training in ERP \\
\cline { 2 - 2 } & Capital Operation Case Analysis \\
\hline \multirow{2}{*}{ Risk management ability } & Stakeholder Management Case Analysis \\
\cline { 2 - 2 } & Internal Audit Case Analysis \\
\cline { 2 - 2 } & Internal Control System Design \\
\cline { 2 - 2 } & Risk Management and Control Case Analysis \\
\hline
\end{tabular}

\subsubsection{Comprehensive Practice.}

In comprehensive practice level, students' ability of finding the problems, analyzing the problems, solving the problems and innovatory capability should be seriously cultivated. The goal of cultivating students' value creation ability should be further strengthened in this level. It has been pointed out in the Opinions on Vigorously Promoting the Innovation and Enterprise Education in Institutions of Higher Learning and College Students Self-employment issued by the Ministry of Education in 2010: "Effectively involve the innovation and enterprise education into the teaching program of professional education and culture quality education and credit system, to establish a multi-level, three-dimensional innovation and enterprise education curriculum system. Highlight the professional characteristics, and actively promote the reform on talent training mode, teaching content and curriculum system, with entrepreneurial innovation courses combined to professional curriculum system, and the entrepreneurial innovation practice connected to professional practical teaching. ${ }^{[2]}$. Comprehensive practice teaching contents include all kinds of disciplines competition, production, 
teaching and research activities, graduation practice and graduation thesis, entrepreneurial innovation practice and social services. For example, challenge cup venture competition, accounting skills contests, financial management decision-making competition, scientific research projects and so on. Taking graduation thesis as an example, in terms of topic direction, students can start on by tightly surrounding different links of enterprise value management activities, which plays an irreplaceable role in improving students' professional quality.

The multi-level and multi-steps curriculum construction mentioned above could gradually and steadily push forward the practical teaching system of financial management from junior to senior stage, and can realize the hierarchical cultivation to meet different market demands. With the development of science and technology as well as the progress of information, practical teaching methods and means develops with each passing day, and thus the practical teaching content of each level need to be constantly improved. The improvement of the practical teaching content should always take the financial management personnel training mode and training objectives as the guidance, keep up with the educational reform pace, innovate practical teaching, strengthen practical education, to reach the ultimate goal of cultivating financial management talents with value creation ability.

\subsection{Establish Three Dockings to Guarantee Practical Teaching Effect.}

\subsubsection{Theory Teaching Docks with Practical Teaching.}

Corresponding to theory teaching hours, increase practical teaching hours reasonably. For example, add 1 credit of Financial Management Decision-making Training in the Financial Management, 1 credit of The Application of Management Accounting Tools in the Management Accounting, 1 credit of Tax Planning Case Analysis in the Tax Administration, 1 credit of Internal Control System Design in the Internal Control.

\subsubsection{The First Classroom Docks with the Second Classroom.}

The part of core and leading front practical teaching courses such as Capital Operation Case, Analysis Stakeholder Management Case Analysis, Risk Management and Control Case Analysis can be set up as elective courses in the second classroom for students to study selectively. The second classroom can be carried out by inviting industry experts in short semester or spare time.

\subsubsection{Social Practical Activities Docks with Professional Internship and Practice.}

Students can collect materials by taking part in different social practical activities, thus make a full preparation for their writing the cases of professional practical courses, application for science research projects and composing graduation thesis, realizing the docking of social practical activities with professional internship and practice.

\section{Conclusions}

Taken as the soul, the goal orientation taken is the most important part of constructing financial management practical teaching system. Surrounding around this goal orientation, we put forwards the ideas of hierarchically constructing financial management practical teaching content system. The content system can be divided into three levels: basic practice, professional practice and comprehensive practice. In the level of professional practice, we present some financial management core practical teaching innovative courses and introduce how to put these courses into good use in the process of practical teaching. At last, we provide three dockings to guarantee practical teaching effects.

\section{Acknowledgement}

This work is supported by a grant from National Statistics Science Research Project (Project No. 2015LZ43) and a grant from Science and Technology Plan Project of Guangdong Province (Project No. 2014A080804001). 


\section{References}

[1]. Ministry of Finance of China, "The Guidance with respect to comprehensively promoting management accounting system construction”, 2014.

[2]. Li Dongmei, The Construction of Innovation-oriented Accounting Practical Teaching System [J]. Friends of Accounting, 2011 (1)

[3]. Zhu Huajian, Study on Chinese Enterprises Financial Management Capacity System Construction and Ctertification [D] , Donbei University of Finance and Economics,2013

[4]. Chao Jian, The Analysis and Thinking of Chinese College Financial Management Professional Practice Teaching Present Situation [J], Capital University of Economics and Business academic journal, 2009

[5].Liu Jianyong, Zhu Xueyi, Zhu Liangfeng, Re Employment-oriented Accounting Practical Teaching System [J], Journal of Shanxi University of Finance and Economics (higher education). 2010 (9)

[6].Wang Xiankang, Wang Minghua. Research on Accounting Practical Teaching System in Independent Colleges [J]. Chinese Management Informationization. 2009 (4) 